\title{
EXPLORATION OF SEA CUCUMBER INTESTINAL SYMBIONT MICROBE AS PROBIOTIC MICROBE CANDIDATE IN HEALTHCARE PRODUCTS
}

\author{
Putri Hutari Girsang, Delianis Pringgenies*, Ervia Yudiati, Gunawan Widi Santosa, Ali Djunaedi \\ Department of Marine Science, Faculty of Fisheries and Marine Science, \\ Diponegoro University, Semarang, Indonesia \\ *Corresponding author: pringgenies@yahoo.com
}

\begin{abstract}
Natural ingredients from animals and plants generally have potential in pharmaceutical applications. However, there still relatively little exploration made on the active ingredients from marine life. Sea cucumbers inhabit seabed and are filter feeders, consuming all microorganisms within their vicinity, which opens the prospect of medicinal applications of sea cucumber intestinal symbiont microbes. This study aims to obtain sea cucumber intestinal symbiont microbes with a potential pharmaceutical applications as probiotic microbe candidates. The study was carried out by collecting samples, microbe isolation, antimicrobial screening, identification of potential probiotic microbe candidates. Characteristics of the microbe were studied by biochemical screening and molecular identification. The study found 21 microbial isolates from Holothuria atra and 30 microbial isolates from Holothuria leucospilota. Antimicrobial activity screening results against pathogens of Bacillus cereus dan Pseudomonas aeruginosa showed that 13 microbial isolates with positive activity. Four species were identified by molecular identification, namely Bacillus aquimaris, Bacillus maritimus, Bacillus toyonensis, and Virgibacillus chiguensis, whereas the other nine were identified by biochemical screening. Four microbe genus, namely Rothia sp., Listeria sp., Micrococcus sp., and Staphylococcus sp, were found to be the most viable candidate for probiotics. It was concluded that Bacillus sp., Rothia sp., Micrococcus sp., and Staphylococcus sp. exhibited the most potential as probiotic microbes.
\end{abstract}

Keywords: Sea Cucumber, Symbiont Bacteria, Probiotic

\section{INTRODUCTION}

Human health is one of important thing in human life. One effort for that is food supplement consumption. Probiotic product known to maintain human health especially for digestive health stability. According to [1] There is increasing evidence in favour of the claims of beneficial effects attributed to probiotics, including improvement of intestinal health, enhancement of the immune response, reduction of serum cholesterol, and cancer prevention.. Probiotic as consortium of microorganism will effect human health. This was since combination of microorganism in probiotic will improve intestinal microflora. Other than intestinal probiotic microorganism also will give positive effect for immunity, urogenital, and allergic effect [2]. The ability of probiotic microorganism is inhibiting virus or pathogenic microorganism as well as other microorganisms that produce lactic acid included as probiotic.

Lactic acid bacteria will change carbohydrates and sugar to become lactic acid. Probiotic had been widely used in food industry. Most of food product using probiotic will have sour taste because of fermentation process [2].

Exploration of probiotic bacteria can be isolated from the symbiotic organism in the intestinal organism of Holothuria atra and Holothuria leucospilota. Research of [3] had isolated probiotic bacteria from rumen of cow used for human health. A study of [4], showed that probiotic bacteria from the intestine of catfish can be used in fermentation. This can be supporting evidence that probiotic bacteria isolation of any organism can be applied for human health. Sea cucumber as marine 
invertebrate known as a filter feeder which means that sea cucumber will only feed on suspended particles in the seawater [5]. So that can be assumed that symbiotic bacteria in sea cucumber intestine can be potential for probiotic.

Based on that, the aim of this study is to explore the bacterial species in sea cucumber intestine as potential candidate for probiotic based on isolation, bacterial screening and biochemical test.

\section{MATERIAL AND METHOD}

Sample of symbiotic bacteria was collected from the two species of sea cucumber $H$. atra and $H$. leucospilota from Bandengan Beach, Jepara. Bacterial isolation was conducted in Tropical Marine Biotechnology Laboratory, Faculty of Fisheries and Marine Science, Diponegoro University.

\section{Isolation and purification of symbiotic bacteria}

One milliliter macerated sea cucumber intestine suspended with $5 \mathrm{ml}$ sterile seawater to obtain a serial dilution from $10^{-1}$ to $10^{-5}$ dilution. Diluted bacteria will be isolated with pourplate technique on Zobell agar medium and incubated for 48 hours [4]. Characteristics of the bacterial colony would be observed to identify form, elevation, margin, size, and colour. Each colony will be purified and incubated for $2 \times 24$ hours to obtained single colony. [6].

\section{Screening of antibacterial activity}

Screening of bacterial activity using the overlay method. Bacterial isolate inoculated in Zobell agar medium and incubated for 48 hours at $38 \mathrm{C}$ temperature. Pathogenic bacteria of Pseudomonas aeruginosa and Bacillus cereus growth on $10 \mathrm{ml}$ liquid medium for 24 hours. One milliliter culture of pathogenic bacterial added to soft Zobell agar medium and poured on a petri dish with bacterial inoculate and incubated for 48 hours [7].

\section{Antibacterial activity test}

Antibacterial activity was tested using diffusion technique on a paper disk (Kirbybauer test). Result of bacterial isolate screening would be extracted using centrifuge to get supernatant. Culture of pathogenic bacteria was added into Zobell agar medium using swap method. Sterile paper disc was dipped into bacterial supernatant and medium content was put on medium with pathogenic bacteria. Petri dish incubated for $2 \times 24$ hours and observed inhibitory zone around isolate [8].

\section{Biochemical test}

Identification including macroscopic identification that are gram bacterial colour, spore test, motility test, and anaero/b test. Biochemical test including of catalase test, oxidase test, and glucose test [9].

\section{RESULT AND DISCUSSION}

\section{Isolation and bacterial colony characteristic}

Isolation result from sea cucumber intestine produce 51 isolate with 21 isolates from Holothuria atra and 30 isolates from Holothuria leucospilota. Each colony was characterized by its form, elevation, margin, size, and colour. Types of colonies form were circular, irregular, spindel, filamentous, and rhizoid. Types of elevations were flat, raised, convex, and umbonate. Types of margins were entire, lobate, serrate, filamentous, and undulate. Colonies size were punctiform, small, moderate and large. Colours of the colony were creamy white, white, creamy yellow, yellow, orange, pink, and also transparant. The form of bacterial colony was effected of growing and enviromental factor as biotic and abiotic, nutrition and temperature [10]. The colour if this natural pigment can be use for many other used in human health such as anti-tumor, antiinflamation, anti-obesity and increase brain ability and antioxidant. 
Table 1. Characteristic identification of bacterial colony

\begin{tabular}{|c|c|c|}
\hline & \multirow{3}{*}{$\begin{array}{c}\text { Bacterial Code } \\
\text { TB } \\
\text { TH } \\
\end{array}$} \\
\hline & & \\
\hline & Morphology & \\
\hline \multirow{10}{*}{ Form } & Circular & 12 \\
\hline & & 13 \\
\hline & Irregular & 16 \\
\hline & & 6 \\
\hline & Spindel & - \\
\hline & & 1 \\
\hline & Filamentous & 1 \\
\hline & & 1 \\
\hline & Rhizoid & 1 \\
\hline & Flo & $\frac{-}{17}$ \\
\hline \multirow{7}{*}{ Elevation } & Flat & $\begin{array}{l}17 \\
14\end{array}$ \\
\hline & Raised & 4 \\
\hline & & 1 \\
\hline & Convex & 8 \\
\hline & & 5 \\
\hline & Umbonate & 1 \\
\hline & & 1 \\
\hline \multirow{10}{*}{ Margin } & Entire & 12 \\
\hline & & 12 \\
\hline & Lobate & 11 \\
\hline & & 6 \\
\hline & Serrate & 3 \\
\hline & & 2 \\
\hline & Filamentous & 1 \\
\hline & & 1 \\
\hline & Undulate & 3 \\
\hline & & - \\
\hline \multirow{8}{*}{ Size } & Punctiform & 5 \\
\hline & & 5 \\
\hline & Small & 12 \\
\hline & & 10 \\
\hline & Moderate & 7 \\
\hline & & 3 \\
\hline & Large & 6 \\
\hline & & 3 \\
\hline \multirow{13}{*}{ Colour } & Creamy white & 11 \\
\hline & & 10 \\
\hline & White & 1 \\
\hline & & 4 \\
\hline & Creamy yellow & 5 \\
\hline & & 3 \\
\hline & Yellow & 6 \\
\hline & & 1 \\
\hline & Orange & 2 \\
\hline & & 1 \\
\hline & Pink & 1 \\
\hline & Transnarant & $\overline{4}$ \\
\hline & & 2 \\
\hline
\end{tabular}

\section{Antibacterial Activity Test}

Antibacterial test become one important step in bacterial exploration for probiotic candidate for pathogenic inhibition. Thirteen isolates resulted for pathogenic inhibition are P.a B.c where P.a known as bacteri caution for urinary infection and digestive infection [11]. While B.c produce toxin which will cause toxicity [12]. Test result showed that 13 bacteria had capable of inhibiting pathogens.

Table 2. Antibacterial activity test

\begin{tabular}{ccc}
\hline Code & P. aeruginos & B. cereus \\
\hline TH 12 & - & + \\
TH 18 & + & + \\
TH & - & + \\
19.1 & & + \\
TH & - & + \\
20.1 & & + \\
TB 3.2 & - & + \\
TB 16 & + & + \\
TB 18.2 & - & + \\
TB 23 & - & + \\
TB 29 & - & + \\
TB 12 & - & + \\
TH 15 & - & + \\
TB 7 & - & \\
TH 20 & - & \\
\hline
\end{tabular}

\section{Biochemical Test}

All bacteria that can pass through the antibacterial test will be identified. Four isolates from two samples of sea cucumber were identified using molecular method [13] are Bacillus aquimaris TF-12 (TB 12), Bacillus maritimus KS 16-9 (TH 15), Bacillus toyonensis BCT-7112, dan Virgibacillus chiguensis NTU-101 (TH 20). Another 9 bacterial such as TH 18, TB 3.2, TB 16, TB 18.2, TH 20.2, TH 12, TH 19.1, TB 23, and TB 29 had been identified using biochemical test to genus level.

Bacterial gram test indicates 9 isolates as gram positive bacteria. According to [14] that gram positive bacteria can be classified as probiotic. According to [15], characters of gram positive bacteria are they have thick cell wall and do not have the outer membran. In contrast, gram negative bacteria have thin cell 
wall in between two layers of their cell membrane. Gram positive bacteria will have purple colour because of peptidoglican bind the crystal violet and gram negative will showed red colour because of safranin [16].

In aerobic respiration, the oxidative enzyme will role in the process of electron transfer [16]. The negative result on bacteria TH 18, TB 3.2, TB 16, and TB 18.2 assumed that these bacteria don't have an oxidative enzyme. Bacterial with the positive result which can produce oxidative enzymes are $\mathrm{TH}$ 20.1, TH 12, TH 19.1, TB 23, dan TB 29. Bacterial with negative oxidase belongs to anaerob bacteria while positive oxidase as aerobic bacteria. Oxidation reaction was depend on the presence of peroxide and perioxidase. The presence of enzyme as catalysis of cytochrome oxidase will be reducted by molecular oxygen in electron transfer process. Most of aerobic and anaerobic facultative bacteria will have cytocrome system in aerobic respiration [17].

Nine bacterial candidates have negative spore that showed not producing spore. Results of 9 probiotic candidate bacteria in the category of lactic acid bacteria that are gram positive, non spore, and have coccus and bacil form [18]. Result of motility test showed that bacteria with code TH 18, TH 20.1, TH 12 , TB 3.2, TB 16, and TB 18.2 have negative motility while bacteria of 19.1 , TB 23 , and TB 29 have positive motility. The presence of positive motility can be assumed that the bacteria have flagel. Flagela in bacteria function as moving organ as structure outside the cell and made from unit of protein. Bacterial with non motility will have limited biosyntethic ability [19].

Table 3. Biochemical identification of bacterial isolate

\begin{tabular}{|c|c|c|c|c|c|c|c|c|c|c|}
\hline \multirow{3}{*}{ No } & \multirow{3}{*}{ Biochemical Test } & \multicolumn{9}{|c|}{ Bacterial Code } \\
\hline & & & TH & TH & TH & TB & TB & TB & TB & TB \\
\hline & & ТН 18 & 20.1 & 12 & 19.1 & 3.2 & 16 & 23 & 18.2 & 29 \\
\hline 1 & Gram & + & + & + & + & + & + & + & + & + \\
\hline 2 & Form & $\mathrm{C}$ & B & B & B & $\mathrm{C}$ & $\mathrm{C}$ & B & $\mathrm{C}$ & B \\
\hline 3 & Catalase & + & + & + & + & + & + & + & + & + \\
\hline 4 & Oxidase & - & + & + & + & - & - & + & - & + \\
\hline 5 & Spore & - & - & - & - & - & - & - & - & - \\
\hline 6 & Glukosa carb & Fer & - & - & - & - & - & - & - & - \\
\hline 7 & Glukosa acid & + & + & + & + & + & + & + & + & + \\
\hline 8 & Anaerob & + & - & - & - & + & + & - & + & - \\
\hline \multirow[t]{2}{*}{9} & Motility & - & - & - & + & - & - & + & - & + \\
\hline & & 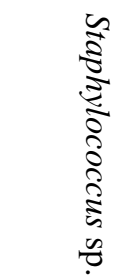 & $\begin{array}{l}\vec{Z} \\
\vdots \\
\vdots \\
\vdots \\
\vdots \\
0 \\
0\end{array}$ & 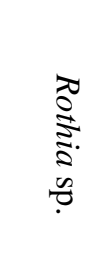 & 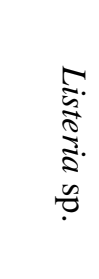 & 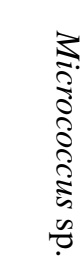 & $\begin{array}{l}\vdots \\
\vdots \\
\vdots \\
\vdots \\
\vdots \\
\vdots \\
0\end{array}$ & 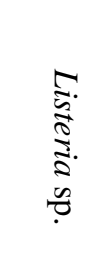 & 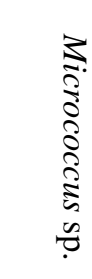 & 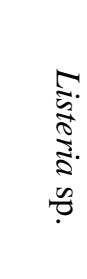 \\
\hline
\end{tabular}

Note:

$\mathrm{C}$ : Coccus, B : Bacil, Fer : Fermentation 
Biochemical test for identification indicate for genera of bacteria that are Staphylococcus sp. (TH 18), Micrococcus sp. (TB 3.2 dan TB 16), Rothia sp. (TH 20.1), and Listeria sp. (TH 19.1, TB 23, dan TB 29). Although having pathogenic inhibitory as probiotic should be non pathogenic for human being and give benefit for the host organism. Benefit of bacteria will be different from one to another but sometime will have similar clinical benefit [20]. According to [21], that probiotic candidate from intestinal target will support the growth of probiotic in the intestine.

Staphylococcus sp. as gram-positive bacteria can cause pathogens. However, research of [22], prove that Staphylococcus sp. with negative coagulase (CNS) is known as a non-pathogenic bacterium and acts as a good probiotic. The negative coagulase Staphylococcus can be used as antitubercular. Staphylococcus hominis is one type of the Staphylococcus genus capable of being a probiotic candidate because it has the ability as antimicrobial activity [23].

Micrococcus sp. can be easily found in the environment. This bacteria known as normal skin microflora and have antibacterial activity against several pathogens [24]. Not much research has been done to explore this bacteria. Potential of Micrococcus sp. besides the ability to be antibacterial, it also has the potential as an antioxidant. One type of this bacteria namely Micrococcus luteus is able to produce exopolysaccharides. This bioactive ability can be utilized as an antioxidant [25].

Rothia sp. is a gram positive bacterium that belongs to phylum of Actinobacteria. These bacteria can be found in the oral cavity, respiratory tract, and duodenum. Rothia sp. has the ability to degrade physiologically dangerous gluten peptides. Colonization of the duodenum with these bacteria can reduce gluten level due to Rothia sp. capable of producing the gluten degrading enzymes [26]. Listeria sp. classified into facultative bacteria and included in gram-positive bacteria. The bacteria live in optimal temperatures of 24-37 ${ }^{\circ} \mathrm{C}$ and have size range of $0.4-2.0 \mu \mathrm{m}$ [6]. The bacteria can be motile at temperature of $28{ }^{\circ} \mathrm{C}$ and non-motile at $37{ }^{\circ} \mathrm{C}$ [26]. The genera has 6 species, namely L. monocytogenes, $L$. innocua, $L$. seeligeri, $L$. welshimeri, $L$. ivanovii, and $L$. grayi. Three types of Listeria sp. group are known to be pathogenic that infectious to human, namely $L$. ivanovii, $L$. seeligeri, and L. monocytogenes which are currently better known in the world of health [28]. Even though it is found in the intestine, this bacterium is thought not to qualify as a candidate for probiotics because it has a greater potential for pathogenic properties.

Bacillus sp. is a facultative bacterium and belongs to the category of gram-positive. The biochemical properties of these bacteria include positive catalase and oxidase and have spores [6]. Some strains of Bacillus sp. have potential function as probiotics. Bacillus sp. has higher acid tolerance and better stability during heat processing and low temperature storage. Exploration of Bacillus sp. as probiotics show the ability to produce antimicrobial peptides and small extracellular effector molecules [22].

Genus Virgibacillus sp. is a gram positive bacterium, motile, and has spores. [29]. The results of species identification showed that TH 20 isolate had an identical character to Virgibacillus chiguensis NTU101. So far, there is still a lack of information about the use or application of biological activity from Virgibacillus chiguensis [30].

\section{CONCLUSION}

Based on the results of identification of symbiotic bacteria from sea cucumber, not all genera are able to become candidates for probiotics that are good for human health. The sea cucumber intestinal bacteria symbionts that can be a candidate for probiotics for health are Staphylococcus sp., Micrococcus sp., Rothia sp., and Bacillus sp. 


\section{REFERENCES}

[1] Kechagia, M., Basoulis, D., Konstantopoulou, S., Dimitriadi, D., Gyftopoulou, K., Skarmoutsou, N., \& Fakiri, E. M. (2013). Health benefits of probiotics: a review. ISRN nutrition, 2013, 481651 . doi:10.5402/2013/481651

[2] Freitas, M. (2017). The benefits of yogurt, cultures, and fermentation (Chapter 24) The microbiota in gastrointestinal pathophysiology (pp. 209-223). Elsevier Inc

[3] Aqil, H., D. Risdianto, I. Hartati. 2015. Isolasi dan Pengayaan Bakteri Lactobacillus dari Rumen Sapi. Momentum 11 (2).

[4] Indarto, A. F., A. Sulistyarsi., M. W. Ardhi. 2017. Isolasi Bakteri Probiotik dari Usus Ikan Lele Untuk Fermentasi Yoghurt Sebagai Bahan Modul Berbasis Riset dan Keterampilan Proses Sains. Prosiding Seminar Nasional SIMBIOSIS II

[5] Jasmadi. 2018. Pertumbuhan dan Aspek Ekologi Teripang Pasir Holothuria scabra Pada Karamba Jaring Tancap di Perairan Lairgangas, Maluku Tenggara. Jurnal Ilmu dan Teknologi Kelautan Tropis 10 (2) : 317-331.

[6] Subagiyo dan A. Djunaedi. 2011. Skrining Kandidat Bakteri Probiotik dari Saluran Pencernaan Ikan Kerapu Berdasarkan Aktivitas Antibakteri dan Produksi Enzim Proteolitik Ekstraseluler. Indonesian Journal of Marine Science 16 (1) : 41-48.

[7] Saputri, R. A., N. Widyorini., P. W. Purnomo. 2016. Identifikasi dan Kelimpahan Bakteri Pada Jenis Karang Acropora sp. di Reef Flat
Terumbu Karang Pulau Panjang Jepara. Journal of Fisheries Science ad Technology (IJFST) 12 (1) : 35-39.

[8] Madilana, R. N., D. P. Wijayanti., A. Sabdono. 2018. Bakteri Simbion Karang Porites dari Perairan Gunungkidul, Yogyakarta dan Aktivitas Antibakteri Terhadap Bakteri Patogen Staphylococcus aureus dan Escherichia coli. Buletin Oseanografi Marina 7 (1) : 43-50.

[9] Pringgenies, D., M., C. Dananjoyo. 2015. Isolasi Bakteri Simbion Moluska Penghasil Senyawa Antibakteri Multidrug Resistant (MDR).

[10] Ilyas, S. 2001. Mikrobiologi Dasar Diklat Kompilasi 28. Universitas Sumatera Utara Press, Medan

[11] Kining, E., S. Falah., N. Nurhidayat. 2016. Aktivitas Antibiofilm Ekstrak Air Daun Pepaya (Carica papaya L.) Terhadap Bakteri Pseudomonas aeruginosa Secara In Vitro. Current Biochemistry.

[12] Rahmawati, F., S. H. Bintari. 2014. Studi Aktivitas Antibakteri Sari Daun Bihanong (Anredera cordifolia) Terhadap Pertumbuhan Bacillus cereus dan Salmonella enteritidis. Unnes Journal of Life Science 3 (2).

[13] Pringgenies, D., E. Yudiati., A. Djunaedi., G. W. Santosa. Koesoemadji. 2018. Penelusuran Bakteri Simbion dai Pencernaan Teripang Sebagai Antibakteri Strain MDR (Multi Drug Resistant) Sebagai Bahan Produksi Antiseptik. SK. FPIK. No. 150119/UN7.5.10/LT/2018

[14] Lenkey, H. A. Q dan Soeharsono. 2010. Probiotik sebagai Makanan Fungsional Probiotik. Widya Padjajaran. 
[15] Putri, Y. W., A. E. Putra., B. I. Utama. 2018. Identifikasi dan Karakteristik Bakteri Asam Laktat Yang Diisolasi Dari Vagina Wanita Usia Subur. Jurnal Kesehatan Andalas.

[16] Safrida, Y. D., C. Yulvizar., C. N. Devira. 2012. Isolasi Dan Karakterisasi Bakteri Berpotensi Probiotik Pada Ikan Kembung (Rastrengiller sp.). Jurnal Biologi FMIPA 1 (3) : 200-203..

[17] Antriana, N. 2014. Isolasi Bakteri Asal Saluran Pencernaa Rayap Pekerja (Macrotermes spp.). Saitifika 16 (1) : 18-28.

[18] Steel., K. J. 1961. The Oxidase Reaction As A Taxonomical Tool. Journal Gen. Microbiol 25 : 297-306

[19] Elvira, I., S. Wahyuni., N. Asyik. 2016. Karakterisasi Sifat Biokimia Isolat Bakteri Asam Laktat Yang Dihasilkan Pada Proses Fermentasi Wikau maombo. Jurnal Sain dan Teknologi Pangan (JSTP) 1(2) : 121124.

[20] Sanders, M. E., D. Merenstein., C. A. Merrifield., R. Hutkins. 2018. Probiotics For Human Use. Nutrition Bulletin 43 : 212-225..

[21] Elshaghabee, F. M. F., N. Rokana., R. D. Gulhane., C. Sharma., H. Panwar. 2017. Bacillus As Potential Probiotics : Status, Concerns, and Future Perspective. Frontiers in Microbiology vol. 8.

[22] Khusro, A., C. Aarti., A. Dusthackeer., P. Agastian. 2018. Anti-tubercular And Probiotic Properties of Coagulase-negative Staphylococci Isolated From Koozh, A Traditional Fermented Food of South India. Microbial Pathogenesis Vol 114 : 239-250.
[23] Sung, C., Kim B. G., Kim S., H. S. Joo. 2009. Probiotic Potential Of Staphylococcus hominis MBBL 2-9 As Anti-Staphylococcus aeureus Agent Isolated From The Vaginal Microbiota Of A Healthy Woman. Journal of Applied Microbiology 108 (3) : 908-16.

[24] Akbar, A., U. Sitara., I. Ali., N. Muhammad., S. A. Khan. 2014. Isolation and Characterization of Biotechnologycally Potent Micrococcus luteus Strain From Environment. Pakistan J. Zool. 46 (4) :967-973.

[25] Asker M. M. S., Sayed O. H. E., Mahmoud M. G., Ramadan M. F. 2014. Chemical structure and antioxidant activity of a new exopolysaccharide produced from Micrococcus luteus. Journal of Genetic Engineering and Biotechnology. 12(2): 121-126.

[26] Zamakhchari M., Wei G., Dewhirst F., Lee J., Schuppan D., Oppenheim F. G., Helmerhorst. 2011. Identification of Rothia Bacteria as Gluten-Degrading Natural Colonizers of the Upper Gastro-Intestinal Tract. PLoS ONE 6(9): e24455.

[27] Yuswita, E., S. Nurjanah., W. P. Rahayu. 2016. Identifikasi Listeria spp. Pada Pangan Jajanan Berbasis Ikan Di Kota Bogor. Jurnal Teknologi dan Industri Pangan. 27(1): 10-16

[28] Yehia, H. M., S. M. Ibraheim., W. A. Hassanein. 2016. Prevalence of Listeria Species In Some Foods And Their Rapid Identification. Tropical Journal Of Pharmaceutical Research 15 (5) : 1047-1052.

[29] Wang, C.Y., C. C. Chang., C. C. Ng., T. W. Chen., Y. T. Shyu. 2008. Virgibacillus chiguensis sp. nov. A Novel Halophilic Bacterium Isolated From Chigu, A Previously Commercial Saltern Located In 
Southern Taiwan. International Journal of Systematic And Evolutionary Microbiology 58 : 341345.

[30] Martinez, N. C., A. A. González., L. E. Díaz., E. Tello. 2017. Use of A Mixed Culture Strategy To Isolate
Halophilic Bacteria With Antibacterial And Cytotoxic Activity From The Manaure Solar Saltern In Colombia. BMC Microbiology 17 : 230. 